\title{
Peran Grenteng terhadap Kenyamanan Sirkulasi Pengunjung di Komplek Makam Raja Mataram Kotagede Yogyakarta
}

\author{
Putri Prabu Utami \\ Pengkajian Desain Interior, Pascasarjana ISI Yogyakarta \\ putriprabu0609@gmail.com
}

\begin{abstract}
Abstrak
Kotagede Yogyakarta merupakan peninggalan Kerajaan Mataram di mana terdapat banyak peninggalan arkeologis seperti Watu Gilang dan sisa tembok benteng. Peninggalan kerajaan Mataram kuno Kotagede dapat dilihat di komplek Makam Raja Mataram Kotagede. Komplek Makam Raja Mataram di Kotagede Yogyakarta memiliki gaya arsitektur Hindu. Ciri khas dari bangunan Hindu di Makam Raja Mataram identik dengan pengunaan material batu bata merah dan kapur. Komplek Makam memiliki bangunan berupa tembok pembatas yang bernama grenteng yang penempatannya berada setelah pintu gerbang yang memiliki fungsi sebagai penutup atau pembatas antara ruang dalam dengan ruang luar atau ruang sebelumnya. Tujuan dari penelitian ini untuk mengetahui kenyamanan sirkulasi dengan adanya peranan grenteng pada satu ruang. Penelitian ini merupakan penelitian gabungan, yang bergantung pada kedua bahan pustaka yang relevan serta temuan lapangan seperti observasi dan wawancara. Selanjutnya melakukan analisis data lapangan. Keberadaan grenteng yang berada tepat di tengah pintu memberikan pengaruh terhadap kenyamanan sirkulasi pengunjung. Temuan penelitian menunjukkan kenyamanan sirkulasi dengan adanya peran grenteng dapat dicapai pada satu sisi kiri baik digunakan sebagai sirkulasi masuk maupun keluar. Kenyamanan sirkulasi satu sisi pada komplek Makam Raja Mataram Kotagede berbeda dengan bangunan yang memiliki grenteng seperti di Keraton Yogyakarta maupun makam Raja Imogiri.
\end{abstract}

Kata kunci: kenyamanan, sirkulasi, grenteng

\begin{abstract}
Kotagede Yogyakarta is a relic of the Mataram kingdom where there are many archaeological remains such as Watu Gilang and the rest of the wall of the fort. Relics of ancient kingdom of Mataram Kotagede can be seen in the complex of the tomb of King of Mataram Kotagede. Complex Tomb of King of Mataram in Kotagede Yogyakarta has a Hindu architectural style. The distinctive feature of the building at the tomb of the King of Mataram Hindu identical to the material the use of red brick and limestone. The tomb complex of buildings in the form of the parapet has named grenteng whose post is after the gate has a function as a cover or barrier between the space in the outer space or room earlier. The purpose of this study to determine the comfort of their circulation with grenteng role in one room. This study is a combination, which is dependent on both the relevant library materials as well as the findings of such field observations and interviews. Furthermore, analysis of field data. Grenteng existence which is right in the middle of the door to give effect
\end{abstract}


to the comfort of the visitor circulation. The findings show comfort with their roles grenteng circulation can be achieved on the left side used as incoming and outgoing circulation. Leisure circulation of one hand on the tomb of the King of Mataram Kotagede complex of different buildings that have grenteng like in the Keraton or the tomb of King Imogiri.

Keywords: comfort, circulation, grenteng

\section{Pendahuluan}

Kotagede Yogyakarta merupakan peninggalan Kerajaan Mataram dimana terdapat banyak peninggalan arkeologis seperti Watu Gilang dan sisa tembok benteng. Kerajaan Mataram kuno Kotagede dapat dilihat di komplek Makam Raja yang mana pada area komplek terdapat peninggalan Raja Mataram. Komplek Makam Raja Mataram di Kotagede Yogyakarta memiliki gaya arsitektur Hindu. Ciri khas dari bangunan Makam Raja Mataram identik dengan penggunaan material batu bata merah dan kapur. Meski bangunan komplek Makam Raja Mataram Kotagede memiliki struktur bangunan yang sama dengan bentuk tempat ibadah umat Hindu, namun area di dalamnya merupakan bangunan ibadah yang diperuntukkan sebagai tempat beribadah agama Islam dan ritual kepercayaan Islam Jawa (kejawen). Pembagian area komplek Makam Raja Mataram di Kotagede Yogyakarta, seperti masjid, bangsal, sendang, dan area Makam Raja Mataram. Sendang merupakan kolam di pegunungan yang airnya berasal dari mata air yang berada di dalamnya. Biasanya digunakan untuk mandi dan mencuci pakaian. Keberadaan sendang biasanya berhubungan dengan mitos, tentang asal mula terbentuknya sendang tersebut (Subagyo, 1988).

Pembagian area pada komplek Makam Raja Mataram disesuaikan menurut kebutuhan dan fungsinya. Bangunan tembok sebagai pembatas area pada komplek Makam Raja Mataram merupakan elemen penting dalam ranah arsitektur meliputi elemen lantai, dinding, dan plafon. Jika diamati, bangunan komplek Makam Raja Mataram mengalami perubahan spasial dari private space ke public space atau yang bisa diartikan dari ruang pribadi menjadi ruang publik atau umum. Pada saat ini, setiap area yang ada di dalam area komplek Makam Raja Mataram dapat dipergunakan atau dimasuki oleh masyarakat umum. Tidak terdapat pembagian private space ke public space pada setiap area Makam Raja Mataram Kotagede, hal ini terlihat para pengunjung yang datang dapat memasuki semua area makam sesuai peraturan yang berlaku.

Keberadaan Makam Raja Mataram Kotagede tidak terlepas dari salah satu bangunan yang menutup sirkulasi dari suatu ruang atau area bangunan ke ruang berikutnya, yaitu Grenteng. Grenteng merupakan bangunan yang menyerupai kelir atau gebyok, yang membedakan dua objek tersebut adalah kelir atau gebyok biasanya diletakkan di dalam rumah sedangkan grenteng berada di luar ruang. Fungsi dari dua objek tersebut sama yaitu sebagai pembatas ruang, sedangkan yang membedakan di lain hal adalah materialnya di 
mana, grenteng menggunakan bahan batu bata merah sedangkan kelir atau gebyok biasanya terbuat dari kayu maupun bahan partisi lainnya. Pada area Makam Raja Mataram Kotagede memiliki tiga grenteng yang terdapat di tiga pintu gerbang. Tidak dipungkiri, grenteng yang terdapat di belakang pintu gerbang menjadi partisi penghalang terhadap kenyamanan sirkulasi pengunjung. Hal ini menjadikan pencapaian pengunjung tidak terarah secara langsung setelah melewati gerbang. Struktur bangunan yang tinggi memberikan kesan tertutup apabila pengunjung berada di depan pintu gerbang.

\section{Tujuan Penelitian}

Penelitian ini bertujuan untuk mengetahui kenyamanan sirkulasi pengunjung pada bangunan Mataram Kuno di mana, bangunan Mataram Kuno pada saat ini digunakan sebagai tempat wisata atau ruang publik, beribadah dan ziarah makam. Komplek Makam Raja Mataram Kotagede telah menjadi salah satu tujuan wisata Yogyakarta dengan demikian pengunjung yang datang berasal dari berbagai golongan. Sehingga tujuan penelitian ini untuk mengetahui kenyamanan sirkulasi yang digunakan pada saat ini di komplek Makam Raja Mataram Kotagede.

\section{Pertanyaan Penelitian}

Desain interior memiliki tiga aspek sebagi pembentuk ruang yaitu, lantai, dinding, dan plafon. Tiga aspek dipaparkan oleh D.K Ching (1996) dimana merupakan aspek yang dipakai dalam ilmu arsitek dan desain interior. Pengamatan ini bertempat di Makam Raja Mataram Kuno Kotegede yang memiliki area terbuka sehingga pada area ini terdapat dua dari tiga aspek pembentuk ruang yaitu lantai dan dinding. Pengamatan akan membahas mengenai kenyamanan sirkulasi yang berada di ruang terbuka dan digunakan sebagai ruang publik.

Dari penjelasan di atas yang membahas rumusan masalah, sebagai cara untuk mencari jawaban dari penelitian adalah adanya pertanyaan penelitian. Pertanyaan pada penelitian memiliki fungsi untuk mengetahui mengenai sirkulasi pada ruang terbuka yang digunakan sebagai ruang publik, sehingga pertanyaan yang muncul adalah: Bagaimanakah kenyamanan sirkulasi ruang di komplek Makam Raja Mataram Kotagede dengan adanya peran grenteng di area komplek Makam Raja Mataram Kotagede?

\section{Kajian Pustaka}

Terdapat banyak pembahasan penelitian di Kotagede antara lain mengenai, arsitek, desain, sosial, pariwisata, kerajinan dan dimungkinkan masih banyak pengembangan penelitian mengenai Kotagede namun demikian pembahasan yang mengerucut pada komplek Makam Raja Mataram Kotagede belum banyak dibahas. Pada bidang keilmuan arsitek penelitian yang membahas komplek Makam Raja Mataram di Kotagede mengenai arsitek 
Masjid Kotagede, Apriyanto (2015) dalam Jurnal Arsitek yang berjudul "Akulturasi Budaya dalam Arsitekur Masjid Gedhe Mataram Kotagede”, membahas mengenai akulturasi yang diterapkan pada bangunan Masjid memiliki tiga pengaruh yaitu Islam, Jawa, dan Hindu. RR. Tri Reknoningtyas dalam Tesis yang diterbitkan oleh Universitas Gajah Mada Yogyakarta tahun 2016, berjudul "Aksesibilitas di Kawasan Wisata Heritage Kotagede" membahas secara keseluruhan mengenai akses memasuki kawasan wisata Kotagede yang belum terstruktur. Tesis Keilmuan Arsitek dengan judul lain yang diterbitkan Universitas Gajah Mada Yogyakarta tahun 2014 oleh Wira Kartika dengan judul "Pemanfaatan Ruang Publik di Kampung Alun-alun Kotagede, Yogyakarta (ditinjau dari Seting Fisik dan Seting Aktivitas)" membahas mengenai pemanfaatan dan faktor yang mempengaruhi ruang publik sehingga ruang publik difungsikan sesuai kebutuhan dan aktifitas masyarakat. Pada Jurnal Tata Kota "Tradisional Jawa sebagai Penunjang Pariwisata di Kotagede Yogyakarta" (Tinjauan Estetis) yang dibahas oleh Suratno, S.Fil, M.A (2003) membahas tata kota Kotagede masih mencerminkan kota tradisional yang dapat dilihat dari bangunan yang ada di Kotagede, tinjauan estetika terhadap konsep tata kota Kotagede sebagai penunjang.

Desain yang merupakan keilmuan dengan berbagai cabang salah satunya desain grafis yang memiliki hubungan dengan desain interior maupun keilmuan arsitek. Agus Budi Setyawan (2010) dalam Jurnal yang berjudul "Kajian Alternatif Grafis Lingkungan Heritage Kotagede Yogyakarta" membahas mengenai system signed pada alternatif grafis lingkungan heritage Kotagede dapat memenuhi kebutuhan informasi dari para wisatawan. Pembahasan mengenai wayfinding dapat dilihat pada tesis Lintang Ayomi S diterbitkan Universitas Gajah Mada Yogyakarta (2015), berjudul "Peningkatan Kemudahan dalam Pencapaian tempat di Kawasan Wisata Kotagede Ditinjau dari Elemen-elemen Pendukung Sistem Wayfinding”, pada tesis ini membahasa wayfinding pada lokasi wisata namun demikian tidak membahas wayfinding yang seharusnya ada di komplek Makam Raja Mataram Kotagede.

Dari beberapa jurnal dan tesis di atas telah membahas mengenai Kotagede namun demikian, belum adanya bahasan mengenai komplek Makam Raja Mataram secara menyeluruh, baik dari keilmuan desain maupun arsitek, arsitek maupun desain masih banyak aspek sehingga memiliki celah sebagai ide untuk melakukan penelitian. Penelitian ini mengambil dari sisi aspek sirkulasi yang ada pada desain dan arsitek. Pembahasan pada penelitian ini khusus berlokasi di komplek Makam Raja Mataram Kotagede. Komplek makam Raja Mataram merupakan area pablik yang memiliki ruang terbuka di mana, ruang terbuka pada area komplek makam terdapat prinsip bangunan dalam arsitektur dan desain. Aspek pembentuk ruang dalam arsitektur dan desain D.K Ching (1996), meliputi lantai, dinding, plafon. Grenteng atau kelir (terletak di dalam ruang rumah tinggal) merupakan partisi sebagai bagian dari aspek pembentuk ruang. Partisi dapat dibedakan menjadi dua, yaitu partisi permanen dan partisi semi permanen. Grenteng terdapat pada setiap pintu gerbang. Grenteng atau kelir pada komplek Makam Raja Mataram terletak di setiap gerbang sebagai akses utama untuk memasuki area. Grenteng yang merupakan salah satu elemen bangunan dari dinding yang terbentuk berdasarkan struktur kaki, badan, dan kepala. Kaki 
memiliki fungsi sebagai pondasi, badan sebagai pembentuk dan pembatas ruang, sedangkan kepala apabila tidak terdapat elemen plafon maka berfungsi sebagai pembatas ruang.

Pola tatanan ruang dalam arsitektur dan desain memiliki beberapa komponen yang mana berkaitan dengan keterhubungan antara benda, ruang, dan manusia. Komponen yang ada di dalam arsitektur dan desain diantaranya:

\section{Sirkulasi}

Bangunan baik di dalam ruang terbuka atau tertutup memiliki akses atau jalur sebagai tempat untuk menghubungkan antara manusia dengan ruang. Pergerakan manusia antarruang yang dimulai dari asal ruang sampai bergerak ke ruang tujuan didasarkan adanya penghubung ruang atau sirkulasi. Pergerakan manusia menuju ruang-ruang, terarah sesuai dengan sirkulasi ruang, yang mana pergerakannya disesuaikan dengan waktu melalui sekuen suatu ruang. Pengertian sirkulasi menurut Kamus Besar Bahasa Indonesia adalah peredaran. Pengertian sirkulasi antarruang, atau sirkulasi penghubung ruang menurut ilmu arsitektur adalah pergerakan atau ruang lingkup gerak suatu ruang yang saling berhubungan, baik dengan fungsi, bentuk, dan lain sebagainya. Dari dua pengertian di atas dapat disimpulkan bahwa sirkulasi adalah peredaran atau pergerakan yang menghubungkan antarruang yang saling berhubungan. Sedangkan menurut D.K Ching (1996, halaman 229-267) alur sirkulasi dapat diartikan sebagai "tali" yang mengikat ruang-ruang suatu bangunan atau suatu deretan ruangruang dalam maupun luar, menjadi saling berhubungan.

\section{Sirkulasi Ruang Luar}

Ruang luar adalah suatu ruang yang terjadi dengan membatasi alam dimana pembatasan tersebut terbentuk oleh adanya bidang-bidang vertikal dan horizontal yang mengitari dan melingkupinya, sehingga ruang tersebut akan terasa sebagai suatu wadah yang membatasi pandangan mata. Pedestrian, ramp, area parkir, dan pintu adalah sirkulasi yang berhubungan dengan ruang luar.

Menurut Peter Coleman (2006), salah satu elemen dari rancangan baik arsitek, desain, dan tata kota memiliki jalan atau jalur yang berfungsi sebagai akses menuju bangunan atau ruang tertentu. Kedua konsep tersebut memiliki kenyamanan ruang gerak baik sebagai pengguna normal maupun disable sekalipun memiliki batasan tertentu. Beberapa konsep sirkulasi ruang luar yaitu:

a) Sistem platform: sistem dengan menggunakan platform di mana ruang gerak bagi pejalan kaki menjadikan penghubung antara bangunan satu dengan bangunan yang lain secara terus-menerus baik horizontal maupun vertikal. Dalam menghubungkan antarruang dapat berupa secara langsung maupun tidak langsung.

b) Sistem walk away: merupakan pengembangan dari ruang gerak pejalan kaki secara terus-menerus menuju berbagai macam bangunan pada lokasi tertentu sebagai pusat bangunan yang aktif.

\section{Faktor Pendukung yang Mempengaruhi Kemudahan, Kenyamanan dan} Keamanan 
Terdapat berbagai pertimbangan dalam merancang ruang dalam sarana publik, yaitu aspek kemudahan, kenyamanan, dan keamanan. Ketiga aspek tersebut didapat dari penilaian publik secara keseluruhan terhadap sebuah sarana publik. Perancang harus mempertimbangkan ketiga akses tersebut pada sarana publik. Akses tersebut termasuk akses pada sebuah kawasan sarana publik.

Dijelaskan di dalam undang-undang bahwa penyandang cacat memiliki hak yang sama di dalam aksesibilitas guna memenuhi kebutuhan sehari-hari, terutama di dalam aksesibilitas pada sarana publik. Perlu adanya akses yang baik dan fasilitas khusus yang dapat memudahkan diffable people untuk dapat bergerak dengan bebas di dalam dan di luar sarana publik. Penggunaan material dan pengolahan kontur juga menjadi salah satu faktor pendukung aksesibilitas yang baik pada sarana publik bagi diffable people.

a) Rambu: fasilitas dan elemen bangunan yang digunakan untuk memberikan informasi, arah, penanda atau petunjuk bagi penyandang cacat.

b) Vegetasi: pada bagian landscaping biasanya terdapat vegetasi yang berfungsi sebagai pengarah, peneduh, dan buffering suara atau kebisingan. Selain itu digunakan pula lampu taman, bangku taman dan elemen penghias lainnya seperti bebatuan dan rumput.

c) Penggunaan Material dan Tekstur: material merupakan bahan bangunan, atau secara luas dapat diartikan bahan yang digunakan sebagai komponen-komponen pada bangunan. Material juga ada yang difungsikan sebagai lapisan penutup atau finishing yang digunakan pada komponen kulit bagian bangunan ataupun perkerasan. Material sangat berpengaruh terhadap keindahan dan kenyamanan pada suatu kawasan. Selain itu material juga memberikan kemudahan aksesibilitas bagi sebagian kelompok masyarakat contohnya penyandang cacat. Ada beberapa jenis material yang biasanya lazim digunakan di dalam kawasan bangunan publik, yang mana memiliki kelemahan dan kelebihan bagi tiap-tiap bahannya.

\section{Tatanan Ruang Luar}

a) Sistem Radial: tatanan radial merupakan unsur-unsur baik tatanan terpusat maupun linier. Tatanan ini terdiri dari ruang pusat yang dominan di mana sejumlah tatanan linier berkembang menurut arah jari-jarinya.

b) Sistem Grid: sebuah grid diciptakan oleh dua pasang garis sejajar tegak lurus yang membentuk sebuah pola titik teratur pada pertemuannya. Apabila diproyeksikan dalam dimensi ketiga, maka tatanan grid berubah menjadi satu set unit ruang modular berulang.

c) Sistem Organik: tatanan organik merupakan tatanan yang tidak memiliki ketentuan tertentu, pola pada tatanan ini cenderung abstrak.

d) Sistem Linier: tatanan Linier pada dasarnya terdiri dari sederetan ruang. Ruang-ruang ini dapat berhubungan secara langsung satu dengan yang lain atau dihubungkan melalui ruang linier yang berbeda dan terpisah

e) Ruang Publik: ruang publik (Carr, 1992) dapat didefinisikan sebagai ruang atau lahan umum tempat masyarakat dapat melakukan kegiatan publik yang fungsional maupun kegiatan sampingan lainnya yang dapat mengikat suatu komunitas, baik itu kegiatan 
sehari-hari ataupun berkala. Fungsional dari adanya ruang publik digunakan untuk kegiatan politik, keagamaan, perdagangan, olah raga, meru- pakan ruang dengan keadaan yang penuh damai, dan tempat pertemuan yang tidak bersifat pribadi. Beberapa tipologi ruang publik lapangan, tempat wisata, pasar, ruang terbuka, jalan hijau, sampai dengan tepi laut di mana, dari keseluruhan tipologi ruang publik memiliki fungsi berdasarkan aktifitas pada masing-masing ruang publik.

f) Struktur Ruang: menurut Slamet Muljana di dalam buku Runtuhnya Kerajaan Hindu Jawa dan Timbulnya Negara-Negara Islam di Nusantara (2005) menjelaskan stuktur ruang pada masa Mataram di Jawa memiliki sifat yang monosentris hal tersebut mengartikan bahwa prinsip mikrokosmos dualitis hanya memainkan peranan yang kecil. Struktur ruang yang dualitis memang masih dapat kita jumpai di daerah Khadarmadyaksa atau daerah Kepatihan. Tetapi struktur bangunan yang dualitis memiliki kesan tidak terlalu kuat karena perbedaan daerah di mana, daerah Kepatihan jauh lebih kecil dibandingkan dengan keraton atau pura. Dengan demikian peranan Kepatihan dan Khadarmadyaksa di dalam kehidupan politis dan keagamaan tidak terlalu penting. Penjelasan Slamet Muljana berbeda dengan penjelasan yang dipaparkan oleh Miclaine Pont pada buku Jo Santoso (2008) bahwa struktur bangunan Mataram di Jawa menggunakan prinsip dualitis sebagai penghubung antara Kerajaan dengan Khadarmadyaksa yaitu hubungan kedua daerah kauman Siva dan Buddha yang berada di sebelah selatan kota menghubungkan kedua bagaian Kota Utara dan Selatan yang sakral sehingga dapat ditarik kesimpulan bahwa struktur ruang dibangun berdasarkan tingkat kesakralan.

\section{Metode Penelitian}

Pendekatan kualitatif merupakan bagian penting pada penelitian. Pendekatan kualitatif memiliki beberapa metode salah satunya adalah observation dan wawancara kepada juru kunci di area komplek Makam Raja Mataram. Pendekatan kualitatif digunakan sebagai cara untuk melihat kenyamanan sirkulasi di area komplek Makam Raja Mataram Kotagede.

Selain metode observasi dan wawancara yang digunakan sebagai cara untuk mendapatkan informasi, juga melihat sudut pandang dari pengamat dan strategi. Sudut pandang yang dimaksud adalah posisi sebagai pengamat penelitian sehingga dalam penelitian ini sudut pandang yang digunakan berada di dalam (emik). Strategi yang digunakan dalam pengambilan data adalah terlibat di mana selain mengamati pengguna sirkulasi juga ikut berada di posisi pengguna sirkulasi. Metode ini digunakan untuk mengetahui kenyamanan sirkulasi pengunjung dengan adanya peran grenteng di area komplek Makam Raja Mataram Kuno sehingga posisi penelitian yang berada di dalam dan terlibat akan mempermudah proses pengamatan, wawancara, dan pengambilan data. 


\section{Pengumpulan Data}

Pengumpulan data dilakukan dengan cara pengamatan terhadap objek kasus yaitu pengambilan data pada grenteng ketiga yang berada di area pelataran makam dan sendang komplek Makam Raja Mataram Yogyakarta. Pengambilan area pada kasus ini berdasarkan bentuk grenteng yang memiliki perbedaan dengan dua grenteng yang berada di pintu gerbang pertama dan kedua komplek Makam Raja Mataram Kotagede. Selain bentuk yang memiliki perbedaan pada area ini merupakan salah satu tujuan dari pengunjung dengan alasan area ini merupakan tempat informasi pengunjung sebelum ke area makam dan sendang. Proses pengamatan dilakukan pada hari Senin, Kamis, dan Jumat yang mana disesuaikan dengan jadwal dari pengunjung yang akan berziarah ke Makam Raja Mataram Kotagede. Pengumpulan data dengan cara menggunkan alat kamera, handycam, alat pengukur (meteran), dan alat tulis. Pemilihan pengambilan data dengan menggunakan video dapat memberikan pengulangan informasi apabila pada saat menyusun laporan ada hal yang dimungkinkan terlewatkan.

\section{Studi Literatur}

Dalam penelitian ini, informasi yang didapatkan selain berdasarkan hasil dari pengamatan yang dilakukan di komplek Makam Raja Mataram Kotagede Yogyakarta, juga dengan menggunakan buku sebagai referensi dan informasi penelitian. Buku sebagai pustaka membantu untuk memberikan informasi yang berkaitan dengan data penelitian. Selain itu, pengumpulan data yang dilakukan dengan wawancara dengan juru kunci makam Raja Mataram Kotagede.

\section{Analisis Data}

Analisis data pada penelitian dilakukan setelah mendapatkan data lapangan yang memberikan informasi mengenai penelitian. Setelah mendapatkan data lapangan, analisis data dilakukan dengan tujuan untuk melihat kenyamanan sirkulasi pada komplek Makam Raja Mataram Kotagede kemudian akan dianalisis berdasarkan pustaka. Data pustaka yang digunakan pada analisis penelitian disesuaikan dengan konsep penelitian.

\section{Keterbatasan dan Kesinambungan Penelitian}

Pada setiap penelitian tentunya memiliki keterbatasan dan kesinambungan yang berdasarkan faktor-faktor tertentu. Keterbatasan pada pengamatan penelitian ini adalah kurangnya jumlah pengunjung sehingga memberikan keterbatasan penelitian. Pengunjung sebagai pelaku untuk data pengamatan kurang begitu beragam apabila digolongkan dalam golongan dewasa, balita, orang tua atau manula, sampai difabel.

Pada penelitian ini yang mengkhusus di area pelataran makam dan sendang untuk melihat sirkulasi pada ruang terbuka atau ruang publik merupakan bagian dari desain dan arsitek. Dengan menggunakan sudut pandang peneliti maka akan dapat dilihat mengenai sirkulasi pada komplek makam dengan mengelompokkan golongan pengguna sampai dengan kenyamanan (ergonomi) dalam desain bangunan. Kenyamanan dapat dikaitkan karena pada dasarnya dalam desain maupun arsitek sampai dengan tata kota, selalu mempertimbangkan produk, kenyamanan, dan lingkungan. 


\section{Temuan dan Pembahasan}

\section{Sejarah Kotagede}

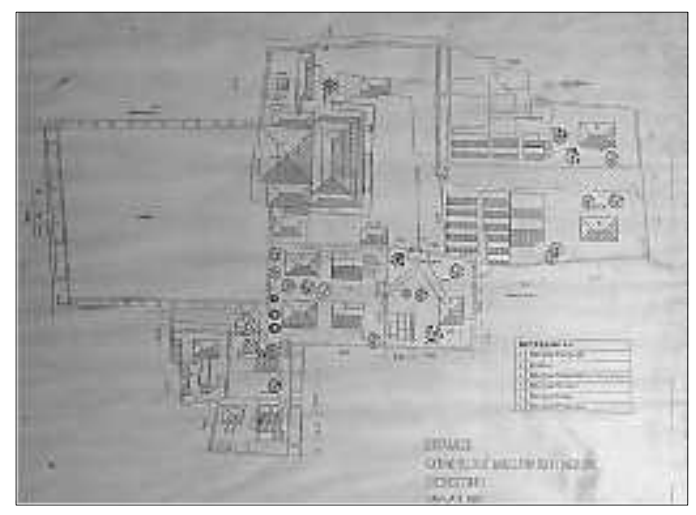

Foto 1. Denah komplek makam Raja Mataram Kotagede Yogyakarta Dokumentasi: Putri Prabu Utami (2016)

Kompleks makam pendiri Kerajaan Mataram berada sekitar 100 meter dari pasar Kotagede. Ada dua benteng yang dibangun, yaitu benteng dalam (cepuri) dan benteng luar (baluwarti), mengelilingi kota yang mempunyai area 200 Ha. Puing bangunan yang masih meninggalkan sejarah Kotagede berada di Dusun Dalem dan Kedaton. Kedua dusun ini berada di bagian tengah yang dahulu dikelilingi tembok cepuri. Tembok keliling (cepuri) tidak simetris di bagian tenggara yang tumpul sehingga oleh warga sekitar mendapat sebutan tempat yaitu bokong semar. Sebelum menjadi area komplek pemakaman, Kotagede dahulu merupakan sebuah kota yang ramai. Seorang peneliti dari Belanda bernama De Haen yang pernah singgah dan meneliti menjelaskan bahwa Kotagede merupakan kota yang luas dengan penduduk yang cukup banyak, tata kota di wilayah ini juga sudah tertata rapi dengan adanya jalanan yang luas dan rapi, terdapat pula banyak lumbung padi. De Haen juga menjelaskan mengenai benteng yang melingkupi Kotagede memiliki tinggi 23 sampai 30 kaki dengan tebal tembok mencapai 4 kaki, sedangkan di bagian luar tembok mengalir parit yang berfungsi sebagai perangkat pertahanan. Dahulu sebelum menjadi pusat Kerajaan Mataram Kuno terutama Mataram Islam, Kotagede merupakan alas Mentaok yang dihadiahkan kepada Ki Ageng Pemanahan sebagai hadiah karena telah mengalahkan musuhnya. Pada saat ini di dalam area komplek makam terdapat makam dari Sutawijaya atau Panembahan Senopati beserta keluarganya. Selain itu, terdapat juga makam dari tokoh Kesultanan Islam Ki Ageng Pemanahan yaitu ayah dari Panembahan Senopati. 


\section{Struktur Bangunan Grenteng Komplek Makam Raja Mataram Kotagede}

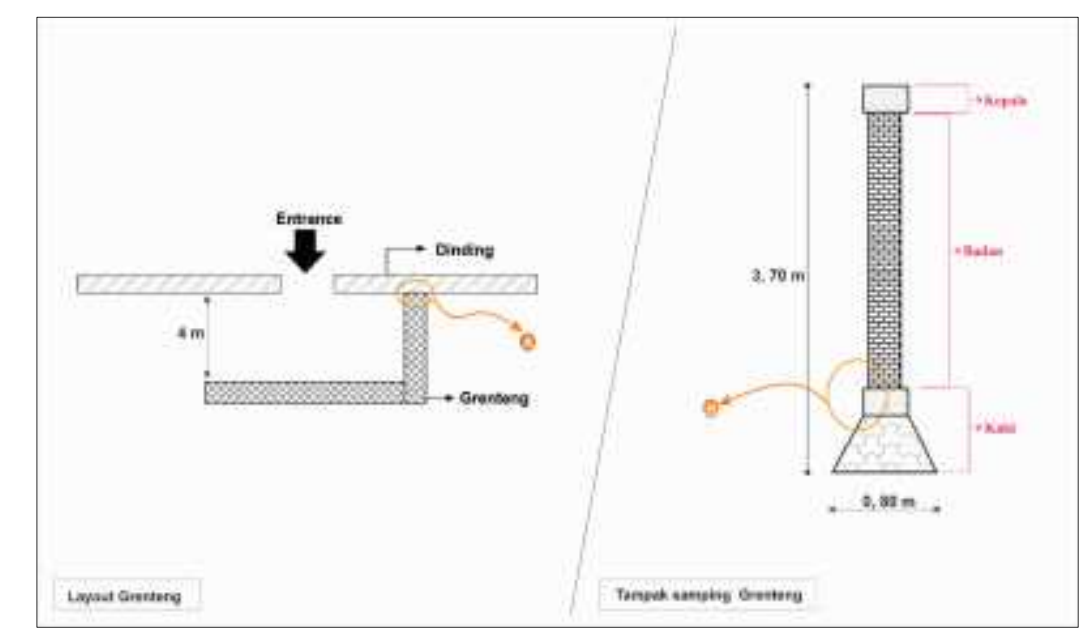

Gambar 1. Layout dan tampak samping bangunan grenteng makam Raja Mataram Kotagede Yogyakarta

Dokumentasi: Putri Prabu Utami (2017)

Komplek makam Raja Mataram Kotagede memiliki tiga bangunan menyerupai pagar atau partisi yang terletak di belakang pintu gerbang. Bangunan dengan nama grenteng (sebutan di komplek Makam Raja Mataram Kotagede) atau kelir merupakan bangunan dengan struktur bangunan dinding yang meliputi kaki, badan, dan kepala. Dua grenteng yang berada di pintu gerbang pertama dan kedua memiliki bentuk dan struktur yang sama yaitu, pondasi yang terletak pada bagian kaki merupakan struktur bangunan Mataram kuno. Hal tersebut dapat dilihat dari buku Jo Santoso (2008), yang membahas struktur bangunan pada masa Mataram kuno belum mengenal batu sebagai struktur bangunan yang terletak pada bagian pondasi (kaki bangunan). Bukti lain pada struktur bangunan ini juga dapat dilihat pada buku Lombard (2000) yang berjudul "Silang Budaya", yang membahas proses masuknya batu bata pada masa Mataram sampai terjadinya Candi Borobudur; sehingga dari hal ini memiliki perbedaan baik struktur maupun bentuk yang ditemui pada grenteng ketiga di gerbang menuju area sendang dan makam Raja Mataram. Seperti yang dipaparkan Lombard (2000) bahwa proses bangunan dan arsitektur di Jawa yang telah menggunakan unsur batu kali atau batu alam, baik sebagai pondasi atau aplikasi pada dinding merupakan pengaruh yang dibawa bangsa Barat ke Indonesia. Hal ini terlihat pada struktur bangunan grenteng ketiga yang terbuat dari batu di bagian kaki (pondasi), dapat dilihat pada gambar 1 yang ditunjukkan dengan huruf B (tampak samping bangunan grenteng). Grenteng ketiga yang memiliki perbedaan tersebut merupakan hasil renovasi setelah masuknya bangsa Barat ke Indonesia, hal ini dapat dilihat pada gambar 1 (tampak samping bangunan grenteng). Sistem penyambungan struktur bangunan grenteng di komplek makam tidak menganut sistem 
bangsa Barat yaitu dengan cara mengunci atau mengaitkan dinding untuk membentuk ruang, akan tetapi sistem penyambungan bangunan pada komplek ini dengan menggunakan sistem menempelkan dinding untuk membentuk ruang. Hal ini dapat dilihat pada gambar 1 yang ditunjukkan dengan huruf A (layout bangunan grenteng). Struktur bangunan yang terbentuk dari penyambungan antardinding hingga terbentuknya ruang pada area komplek Makam Raja Mataram Kuno Kotagede mengalami perubahan pada ruang yang telah terbentuk yang berawal dari ruang privat yang dulunya dipakai oleh kalangan raja dan bangsawan pada masa Mataram, kemudian beralih menjadi ruang publik seiring berkembangnya zaman; dapat dilihat pada buku Arsitektur Kota Jawa Kosmos, Kultur dan Kuasa oleh Jo Santoso (2008). Sehingga secara keseluruhan bangunan pada komplek Makam Raja Mataram Kotagede merupakan bangunan peninggalan Mataram Kuno berdasarkan struktur bangunannya yang secara keseluruhan masih menggunakan sistem penyambungan dengan cara menempelkan antardinding.

\section{Hubungan Pengguna dengan Sirkulasi}

Sirkulasi dalam desain dan arsitek merupakan salah satu peranan penting. Sirkulasi, baik yang berada di dalam ruang maupun di luar ruang, pada dasarnya memiliki fungsi yang sama yaitu sebagai penghubung ruang. Sirkulasi di ruang terbuka pada komplek Makam Raja Mataram Kotagede memiliki sistem konfigurasi jalur grid dimana sistem ini sering digunakan pada bangunan, baik pada bangunan terbukan maupun bangunan yang tertutup (rumah tinggal, toko, kantor, sekolah, dan sebagainya). Keilmuan arsitek dan interior menerapkan konfigurasi jalur sesuai dengan aktivitas dan fungsinya pada bangunan.

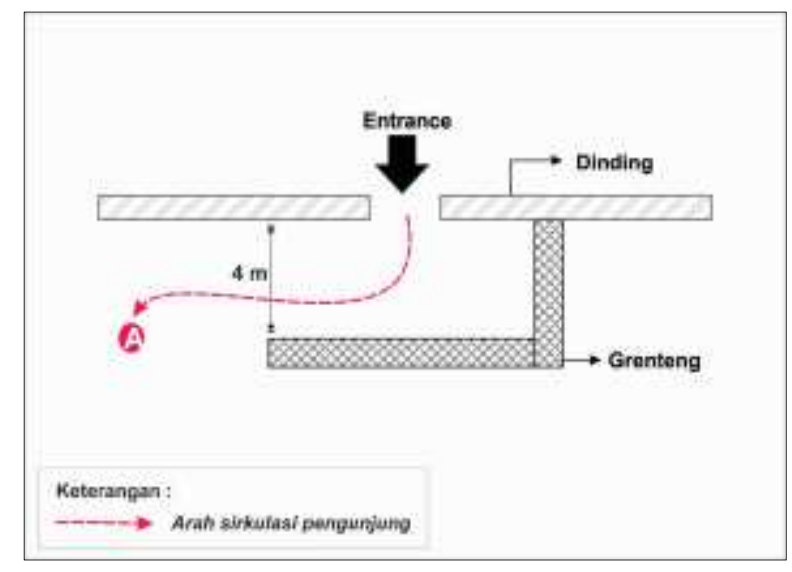

Gambar 2. Layout grenteng pada pintu gerbang 1 dan 2 di komplek makam Raja Mataram Kotagede Yogyakarta Dokumentasi: Putri Prabu Utami (2017)

Gambar di atas menunjukkan posisi grenteng yang berada di pintu gerbang pertama dan kedua yang memiliki bentuk grenteng sama. Sirkulasi yang menjadi penghubung antara ruang luar dengan ruang dalam pada area komplek Makam Raja Mataram terarahkan dengan 
adanya peran grenteng yang memiliki bentuk L (dilihat dari layout), sehingga pengguna akan mengarah pada sirkulasi yang sudah terbentuk. Hal ini dapat dilihat pada petunjuk huruf A pada gambar 2. Garis panah merah merupakan arah sirkulasi yang menghubungkan antarruang. Peran grenteng yang memiliki bentuk L dilihat dari layout pada gambar 2, secara tidak langsung memiliki fungsi sebagai signed antarruang. Signed merupakan peran penting di dalam bangunan terutama pada bangunan public, adanya signed mempermudah pengunjung pada saat berada di area public. Signed pada dasarnya tidak hanya berbentuk tulisan untuk menunjukkan suatu ruang pada area public. Kenyamanan sirkulasi yang berada pada pintu gerbang 1 dan 2 memiliki tingkat kenyamanan yang cukup. Jarak antara grenteng dengan dinding bangunan memiliki lebar 4 meter di gerbang pertama dan 3,5 meter di gerbang kedua sehingga, kenyamanan sirkulasi pengunjung pada saat memasuki ruang dapat dilakukan berjalan sejajar atau berkelompok dengan maksimal enam sampai tujuh orang. Kenyamanan jarak sirkulasi juga cukup untuk ukuran pengunjung asing sekalipun pada saat memasuki gerbang tidak dapat dilakukan secara bersama, melihat pintu gerbang yang menggunakan struktur yang sama dengan ukuran pintu pada bangunan Hindu atau bangunan pura dan rumah di Bali.

Sirkulasi pada pintu gerbang 1 dan 2 dilihat dari elemen material bangunan memiliki kenyamanan bagi pengunjung, dengan menggunakan bahan material batu alam yang diolah menjadi bentuk kotak dengan tekstur yang tidak dihaluskan akan mendukung material lantai pada bangunan luar ruang. Bagi pengunjung pada saat melewati sirkulasi yang ditunjukkan pada garis merah pada gambar 1, tidak merasakan licin pada bagian material lantai. Ditinjau dari pengunjung yang memiliki fisik normal dengan adanya peran grenteng pada pintu gerbang 1 dan 2 yang memiliki bentuk bangunan grenteng sama, akan mempermudah pengunjung yang berada di komplek Makam Raja, baik pengunjung asing maupun pengunjung lokal, hal ini dibuktikan adanya peran grenteng yang menjadi signed, luas sirkulasi antara grenteng dengan dinding bangunan, dan kenyamanan material yang digunakan. Sedangkan hal yang berbeda dapat ditinjau dari pengunjung dengan berkebutuhan khusus (difabel) akan merasa kesusahan di mana, tidak adanya rambu (signed) bagi penyandang difabel tuna netra, sedangkan untuk pengguna yang menggunakan kebutuhan khusus seperti kursi roda atau tongkat akan merasa kesulitan di area ini karena adanya tangga khusus yang berada di pintu gerbang sehingga kenyamanan sirkulasi pada area pintu gerbang sampai dengan peran grenteng akan kurang nyaman. Tidak adanya fasilitas bagi pengunjung difabel menjadikan beberapa oengunjung difabel lebih memilih berada di area depan makam Raja Mataram Kotagede. 


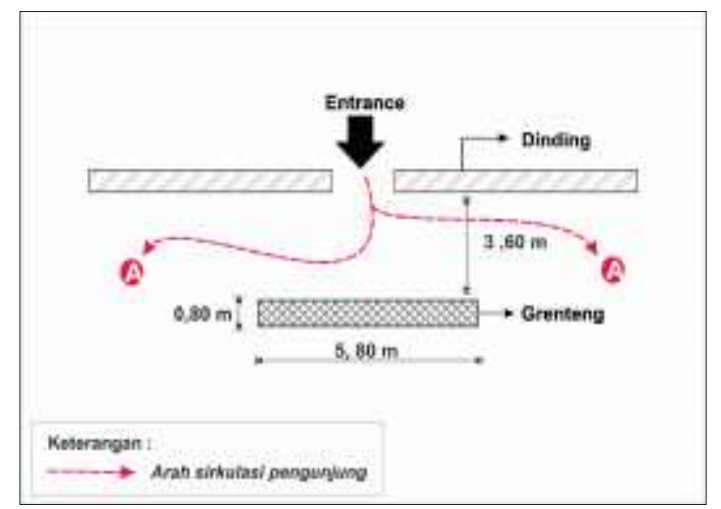

Gambar 3. Layout grenteng pada pintu gerbang 3 di komplek makam Raja Mataram Kotagede Yogyakarta Dokumentasi: Putri Prabu Utami (2017)

Bangunan grenteng yang ketiga terletak di belakang pintu gerbang menuju area inti pada komplek makam Raja Mataram yaitu area makam Panembahan Senopati dan sendang. Grenteng memiliki bentuk huruf I apabila dilihat pada layout gambar 3, tidak seperti dua grenteng sebelumnya pada grenteng ini kenyamanan sirkulasi pengguna memberikan kesan memperlambat akses masuk dikarenakan pengguna yang datang akan terlihat bingung untuk memasuki ruang berikutnya. Peran grenteng yang pada dasarnya sama seperti kelir atau gebyok yaitu sebagai pembatas ruang antara ruang satu dengan ruang laiannya, apabila posisi grenteng yang menyerupai bangunan partisi yaitu terbuat dari material batu bata merah seperti pada grenteng di pintu gerbang ketiga tentunya dengan bentuk I maka akan memberikan sirkulasi dengan dua arah kanan dan kiri, hal ini dapat dilihat pada gambar 3. Adanya sirkulasi dua arah kanan dan kiri yang ditunjukkan pada gambar 3 dengan simbol garis merah, menyebabkan pengguna akan merasakan peran grenteng sebagai penghalang dan penutup ruang sehingga akan ada batas yang dirasakan oleh pengunjung. Kenyamanan sirkulasi dengan peran grenteng yang memiliki bentuk I dilihat pada gambar 3, memberikan kenyamanan sirkulasi ruang tersebut berkurang terlebih dengan peran grenteng yang diposisikan center di antara pintu gerbang. Seperti yang dipaparkan D.K Ching bahwa pencapaian sirkulasi ruang dapat berupa secara tidak langsung dengan adanya faktor tertentu seperti partisi namun demikian pencapaian tersebut harus dibantu dengan adanya faktor lain. Ukuran yang tidak seimbang antara kanan dan kiri merupakan hal yang menjadikan sirkulasi pada gerbang ketiga, untuk masuk dan keluar pengunjung akan menggunakan sisi sebelah kiri dari arah pintu gerbang, hal tersebut karena jarak sirkulasi yang ada di sisi kiri lebih luas dibandingkan dengan kanan. Pada grenteng ketiga dengan ukuran konfigurasi jalan 3,6 meter pada sisi kiri dan $0.75 \mathrm{~cm}$ pada sisi kanan memberikan sirkulasi lebih ke arah kiri.

Kenyamanan material yang digunakan pada lantai sirkulasi di area grenteng ketiga masih sama menggunakan bahan batu kali yang tidak dihaluskan. Ditinjau dari pengunjung 
yang akan memasuki area masih sama dengan peran grenteng 1 dan 2 yang mana, pengunjung dengan fisik normal melewati grenteng ini dapat dilakukan secara berkelompok dan sejajar sedangkan untuk pengunjung difabel belum ada fasilitas yang memberikan kenyamanan pada sirkulasi dengan adanya peran grenteng.

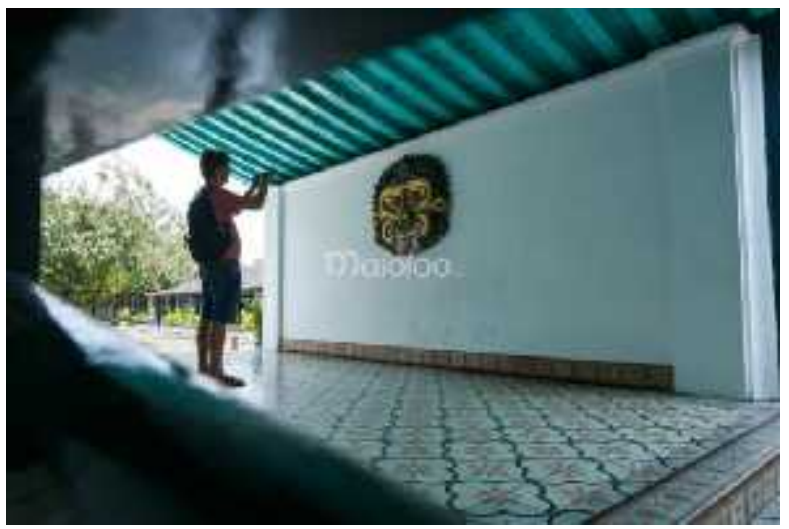

Foto 2. Grenteng atau Kelir pada Pintu Gerbang Keraton Yogyakarta Sumber, https://www.maioloo.com/tempat-wisata/yogyakarta-jogja/keraton-yogyakarta/

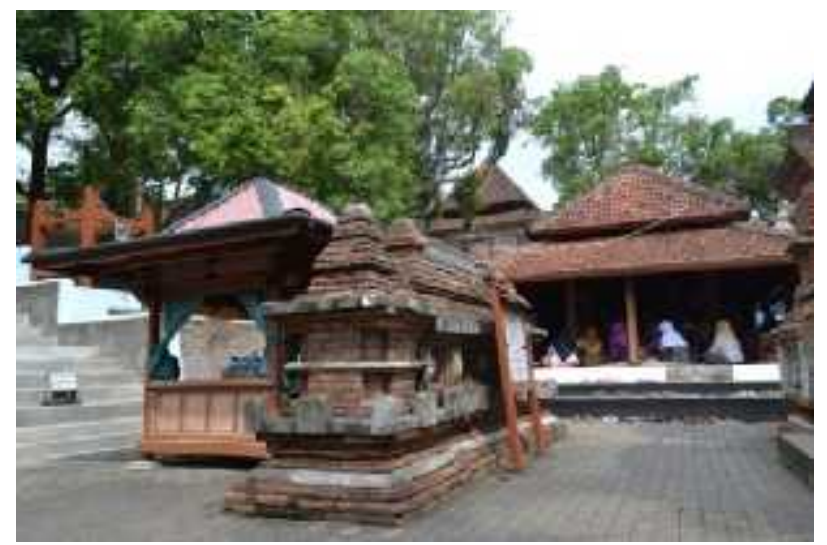

Foto 3. Grenteng di makam Raja Imogiri Yogyakarta Dokumentasi: Putri Prabu Utami (2017)

Berdasarkan informasi melalui wawancara dengan abdi dalem di makam Raja Mataram, peran grenteng pada zaman dulu merupakan alat untuk mengelabuhi penduduk sekitar di mana penyebaran agama Islam pada saat itu dapat dikatakan bersaing dengan agama Hindu, dengan adanya grenteng di posisi depan pintu gerbang maka seseorang dari luar tidak akan dapat melihat bangunan langgar yang sekarang menjadi Masjid Agung Kotagede. Peran grenteng yang sama dapat dilihat di Keraton Yogyakarta dan Makam Raja di Imogiri yang dapat dilihat pada foto 2 dan 3. Sedangkan berdasarkan wawancara dengan 
abdi dalem bahwa pada zaman dahulu fungsi grenteng yang ada di Keraton Yogyakarta sebagai pemisah antara perempuan dan laki-laki pada saat memasuki ruang. Sedangkan pada peran grenteng yang ada di Imogiri sebagai pembatas ruang antara ruang dalam dengan ruang luar, tidak ada yang membedakan pada zaman dahulu mengenai sirkulasi secara gender maupun kebutuhan yang signifikan dengan adanya grenteng. Pada saat ini apabila memasuki area di Keraton dan Imogri pengguna akan merasakan kenyamanan sirkulasi yang mana keseimbangan secara jarak antara kana dan kiri dapat diakses dengan mudah. Sirkulasi yang diciptakan pada area tersebut baik secara material juga memberikan kenyamanan sirkulasi pada pengguna saat memasuki ruang. Bagi pengunjung dengan kebutuhan khusus juga dapat melewati peran grenteng tersebut yang mana terdapat fasilitas bagi pengunjung difabel.

\section{Peranan Grenteng terhadap kenyamanan sirkulasi dan pengguna}

Sirkulasi yang mana berfungsi sebagai penghubung ruang. Sirkulasi pada komplek makam Raja Mataram Kotagede merupakan sirkulasi tidak langsung karena adanya bangunan grenteng yang berada di belakang setiap pintu gerbang. Apabila saling dikaitkan antara pengguna yaitu pengunjung, peranan grenteng, dan sirkulasi maka, grenteng sebagai pembatas ruang yang diletakkan di depan pintu memberikan kesan adanya batasan antara ruang sehingga sirkulasi sebagai penghubung ruang tidak terakses secara langsung walaupun seperti pembahasan di atas dua grenteng di depan secara tidak langsung memberikan signed kepada pengguna. Sehingga hanya pada dua grenteng di depan yang memiliki kenyamanan sirkulasi. Untuk kenyamanan sirkulasi yang berkaitan dengan material pada area komplek dapat memberikan kenyamanan bagi pengguna dengan digunakannya material batu alam di mana tekstur yang digunakan dapat memberikan keamanan (tidak licin). Tidak adanya signed yang diterapkan untuk pengguna difabel, merupakan tidak adanya kenyamanan sirkulasi bagi pengguna difabel. Vegetasi baik yang berupa pohon maupun peneduh lain sudah memberikan kenyamanan bagi pengguna (pengunjung) di mana terdapat beberapa pohon yang ada di area komplek makam, adanya bangsal dan pendopo kecil di beberapa area juga memberikan kenyamanan pengunjung sebagai tempat untuk berteduh.

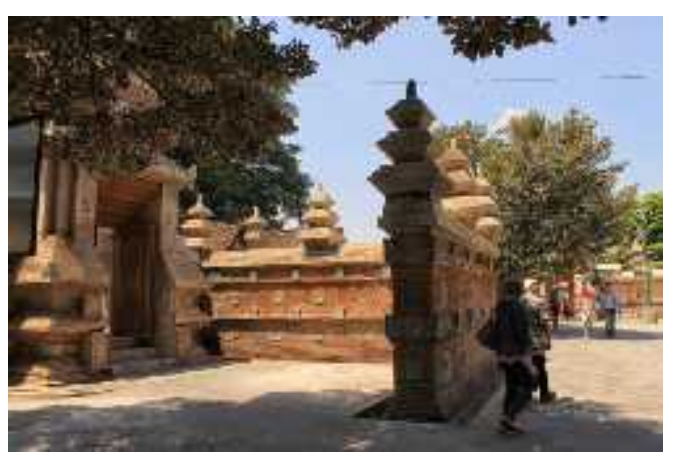

Foto 4. Grenteng kesatu di komplek makam Raja Mataram Kotagede Yogyakarta Dokumentasi: Putri Prabu Utami (2017) 


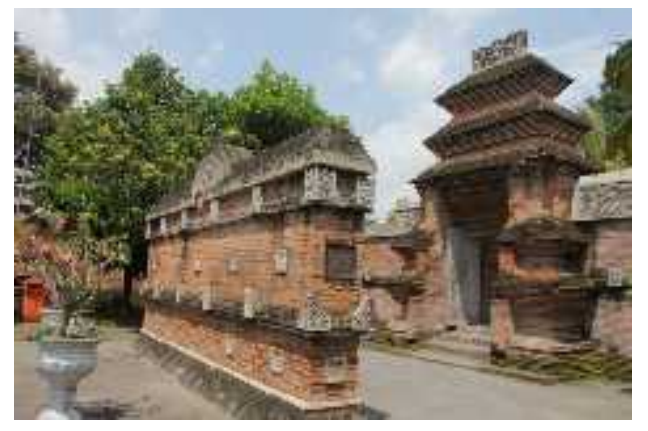

Foto 5. Grenteng ketiga di komplek makam Raja Mataram Kotagede Yogyakarta

Dokumentasi: Putri Prabu Utami (2017)

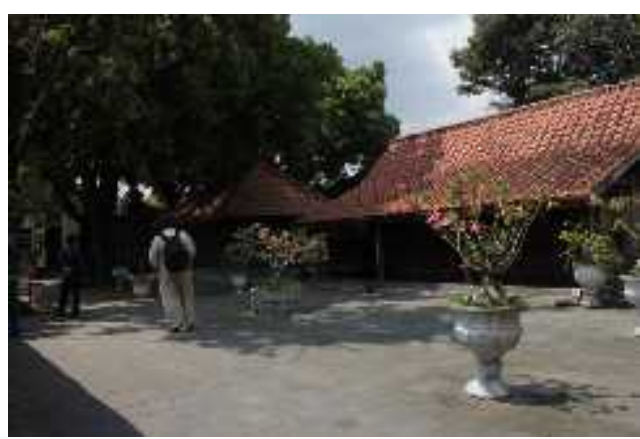

Foto 6. Bangsal berada di kanan dan kiri, area komplek makam Raja Mataram Kotagede Dokumentasi: Putri Prabu Utami (2017)

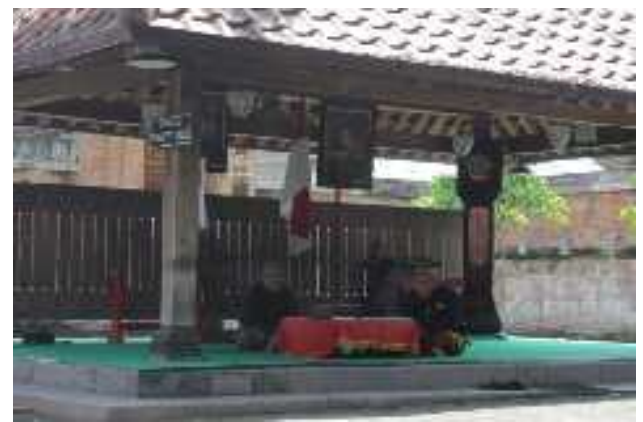

Foto 7. Pendopo berada di kanan dan kiri, area komplek akam Raja Mataram Kotagede Dokumentasi, Putri Prabu Utami (2017) 


\section{Tinjauan Sirkulasi Ruang Luar dengan Pengguna}

Pada kajian pustaka di atas memberikan paparan bagaimana pengguna (pengunjung) di area terbuka dapat merasakan kenyamanan apabila tatanan yang merupakan aspek sirkulasi dapat diterapkan sehingga pengguna (pengunjung) dapat berjalan dengan kenyamanan untuk mengakses ruang ke ruang pada komplek makam Raja Mataram di area pintu gerbang pertama dengan kedua sedangkan akan merasakan kurang nyaman dengan adanya dua sirkulasi dengan ukuran jarak yang berbeda pada pintu gerbang ke tiga. Penerapan ruang gerak pada pengguna (pengunjung) memiliki keterbatasan antara penggiuna normal dengan difabel dimana konsep pada sirkulasi walk away and platform tidak diterapkan pada masa sekarang sebagai bangunan ruang terbuka yang digunakan untuk sarana ruang public sehingga hal tersebut juga akan mempengaruhi rambu (signed) yang merupakan unsur dari kenyamanan pengguna. Hal ini dapat dilihat apabila pengunjung difabel berkunjung ke komplek makam Raja Mataram maka secara sirkulasi akan memmberikan batasan dan kesulitan karena tidak adanya ruang gerak yang sebagai mana mestinya untuk memudahkan pengguna (pengunjung) memasuki ruang.

\section{Kesimpulan}

Dari hasil analisis di atas terkait teori terhadap kondisi di lapangan dapat disimpulkan bahwa struktur bangunan pada komplek Makam Raja Mataram Kotagede merupakan bangunan yang masih menggunakan struktur bangunan pada zaman Mataram kuno sekalipun terdapat perubahan bangunan pada grenteng ketiga. Struktur bangunan grenteng juga terdapat di area Makam Raja Imogiri dengan material yang sama yaitu ciri bangunan Hindu sedangkan grenteng di Keraton Yogyakarta memiliki struktur bangunan yang lebih modern dan sudah dipengaruhi bangunan Belanda atau Indies. Secara keseluruhan struktur bangunan termasuk struktur grenteng masih menggunakan sistem penyambungan bangunan dengan cara menempelkan antarbangunan dinding untuk membentuk ruang, sedangkan hanya pada bangunan grenteng yang ketiga yang menggunakan struktur bangunan modern (pondasi batu).

Sirkulasi pada komplek Makam Raja Mataram Kotagede menggunakan pola sirkulasi grid yang dapat dikaitkan dengan penggunaan sistem single landed. Sirkulasi pada area grenteng ketiga hanya terdapat satu konfigurasi jalan yang berada di sebelah kiri yang memiliki jarak sirkulasi dengan standar yang nyaman bagi pengguna. Kenyamanan sirkulasi pada area komplek Makam Raja Mataram Kotagede hanya akan dapat dirasakan kenyamanan sirkulasinya oleh pengguna (pengunjung) normal sedangkan untuk difabel kenyamanan sirkulasi tidak ditemukan bagi penggunanya. Kenyamana yang memiliki unsur rambu, vegetasi, material hanya unsur rambu (signed) yang belum diterapkan di area komplek Makam Raja Mataram Kotagede. Rancangan tata ruang yang belum menerapkan prinsip yang 
semestinya menjadikan ruang tersebut memiliki keterbatasan bagi pengguna difabel. Peranan grenteng terlihat memberikan fungsi signed yang ditunjukkan secara tidak langsung dengan bentuk bangunannya pada area grenteng satu dan dua sedangkan pada area ketiga peranan grenteng memberikan dua arah sirkulasi yang membingungkan bagi pengunjung dan tidak adanya signed sebagai petunjuk arah masuk ke ruang berikutnya sehingga kenyamanan sirkulasi tidak sesuai dengan pengguna.

\section{Kepustakaan}

Ching, Francis.D.K. 1996. Bentuk, Ruang dan Susunanya. Erlangga.

Coleman, Peter. 2006. Shopping Environments, Evolution, Planning and Design. London.

Santoso, Jo. 2008. Arsitektur kota-Jawa Kosmos, Kultur dan Kuasa. Jakarta: Centropolis. Reknoningtyas, Tri, RR. 2016. “Aksesibilitas di Kawasan Wisata Heritage Kotagede”. [Tesis]. Program Pascasarjana Fakultas Teknik, Universitas Gadjah Mada Yogyakarta.

Kartika, Wira. 2014. "Pemanfaatan Ruang Publik di Kampung Alun-alun Kotagede Yogyakarta (Ditinjau dari Seting Fisik dan Seting Aktivitas)". [Tesis]. Program Pascasarjana Fakultas Teknik, Universitas Gadjah Mada Yogyakarta.

Suratno. 2003. "Tata Kota Tradisional Jawa sebagai Penunjang Pariwisata di Kotagede Yogyakarta (Tinjauan Estetis)". Jurnal Masyarakat dan Budaya, Volume 5 No. 1, Universitas Gadjah Mada Yogyakarta.

Apriyanto. 2015. "Akulturasi Budaya dalam Arsitekur Masjid Gedhe Mataram Kotagede". Jurnal Sejarah Kebudayaan, Vol. 3, Fakultas Adab dan Budaya, Universitas Islam Negeri Sunan Kalijaga Yogyakarta.

Setyawan, Budi, Agus. 2010. "Kajian Alternatif Grafis Lingkungan Heritage Kotagede Yogyakarta”. Jurnal Lintas Grafis, Jurusan Desain, Universitas Mercu Buana Jakarta.

Ayomi S, Lintang. 2015. "Pencapaian tempat di Kawasan Wisata Kotagede Ditinjau dari Elemen-elemen Pendukung Sistem Wayfinding". [Tesis]. Program Pascasarjana Fakultas Teknik, Universitas Gadjah Mada Yogyakarta. 